\title{
Detection of Heavy Metals in Some Seasonings Sold in Some Major Highways in Ogun State, South West, Nigeria
}

\author{
${ }^{1}$ MAKANJUOLA, Olakunle Moses, ${ }^{2}$ OSINFADE, Bashiru Gbolahan \\ ${ }^{1}$ Department of Food Technology, Federal Polytechnic, Ilaro, Ogun State, Nigeria \\ ${ }^{2}$ Department of Science Laboratory Technology, Federal Polytechnic, Ilaro, Ogun State, Nigeria
}

\begin{abstract}
The concentration of some heavy metals such as Iron ( $\mathrm{Fe})$, Zinc ( $\mathrm{Zn})$, Copper (Cu), Chromium $(\mathrm{Cr})$, Lead (Pb), Nickel (Ni), Mercury (Hg), Arsenic (As), Manganese (Mn), Cadmium (Cd) present in five widely consumed seasonings sold along major highways in Ogun state, south west, Nigeria were evaluated using atomic absorption spectrophotometry methods. The study revealed differences in metal concentration in different seasoning samples. The concentration of Iron $(\mathrm{Fe})$ ranged from $0.26 \mathrm{mg} / \mathrm{kg}$ to $1.71 \mathrm{mg} / \mathrm{kg}$ while Zinc $(\mathrm{Zn})$ varied from $0.17 \mathrm{mg} / \mathrm{kg}$ to $1.18 \mathrm{mg} / \mathrm{kg}$. The concentration of Copper $(\mathrm{Cu})$ for all the five samples are $0.28 \mathrm{mg} / \mathrm{kg}$ (onion), $0.56 \mathrm{mg} / \mathrm{kg}$ (nutmeg), $0.76 \mathrm{mg} / \mathrm{kg}$ (garlic), $0.40 \mathrm{mg} / \mathrm{kg}$ (ginger) and $0.21 \mathrm{mg} / \mathrm{kg}$ (Pepper) respectively. While Manganese $(\mathrm{Mn})$ varied between $0.21 \mathrm{mg} / \mathrm{kg}$ to $0.56 \mathrm{mg} / \mathrm{kg}$ for all the samples, the concentrations of both Cadmium $(\mathrm{Cd})$ and Lead $(\mathrm{Pb})$ ranged from $0.001 \mathrm{mg} / \mathrm{kg}$ to $0.01 \mathrm{mg} / \mathrm{kg}$. Nickel (Ni), Mercury ( $\mathrm{Hg})$,Chromium $(\mathrm{Cr})$ and Arsenic (As) concentrations were not detected in all the samples under investigation. The results showed that the level of heavy metals present in these seasonings were lower than those of FAO/WHO limits of 50, 50,100, 300, 100 and 10mg/kg for heavy metals such as $\mathrm{Cu}, \mathrm{Ni}, \mathrm{Zn}, \mathrm{Fe}, \mathrm{Pb}$, and $\mathrm{Hg}$ respectively. Hence, the consumption of these seasonings can not cause any known adverse effect on the consumers health
\end{abstract}

Keywords: Heavy metals, seasoning, Atomic absorption spectrometry, Highways

\section{INTRODUCTION}

The concept of heavy metals includes metals with density greater than $5 \mathrm{~g} / \mathrm{cm}^{3}$. A variety of these metals in the form of trace elements are necessary, essential for many function in human body and their deficiency lead to severe deficiency symptoms (1). Human exposure to toxic heavy metal such as cadmium, lead, copper and zinc is known to be responsible for many human health problems. Contaminated foods are a major source of such heavy metals to man (2). Most heavy metals are non biodegradable and their bio availability and long biological half-life account for their bio accumulation. For man, food form the major non-occupational source of exposure to heavy metals (3) Heavy metals contamination in plant, animal and human are due to environmental pollution through air emission from automobile exhaust, pesticides leaching into water bodies, smelter and process wastes from mining and other industries $(4,5,6,7)$.

A seasoning/spice is a dried seed, front, root, bark or vegetable substance primarily used for flavoring, coloring or preserving food. Sometimes, a spice is used to hide other flavor (8). A spice may have other uses including medicinal, religions, ritual, cosmetics or perfume production, or as a vegetable. For example, turmeric roofs are consumed as a vegetable and garlic as antibiotic (9). Heavy metals have bio-importance as trace element but the bio-toxic effects of many of them in human biochemistry are of great concern as daily traffic increases $(10,11)$. Therefore, this present work is aimed at evaluating some heavy metals that may be present in some seasoning sold along major high ways in Ogun State, south west, Nigeria viz a viz their safety levels

\section{Materials AND Methods}

\subsection{Sample Collection and Preparation}

Sample of five different seasoning/spices viz onion, nutmeg, garlic, ginger and pepper were purchased randomly from five major sales point along the highways, where traffic are extremely high in Ogun state, south west, Nigeria for the purpose of this research work. These samples were transferred to plastic bags and brought to the laboratories for analyses. The samples were washed thoroughly with 
distilled water and rinsed with de-ionized water. They were then (samples) dried in oven between 80$100^{\circ} \mathrm{C}$ for 12 hours, followed by grinding using laboratory mortal and pestle. The dried and grinded samples were then stored in clean, dried and de-contaminated bottles prior to analyses. All glass wares and plastic container used were properly cleaned. Reagent used were of analytical grades.

\subsection{Methods of Analytical Procedure}

\section{Digestion of Sample}

Digestion of sample was carried out by the method of Akagi and Nishimura (12) as reported by Darko et al., (4). About $1 \mathrm{~g}$ of each sample was weighed into a $50 \mathrm{ml}$ digestion tube and $1 \mathrm{ml}_{2} \mathrm{O}$, followed by $2 \mathrm{ml} \mathrm{HCL}, 5 \mathrm{ml} \mathrm{HNO}_{3}: \mathrm{HCIO}_{4}(1: 1)$ and $2 \mathrm{ml} \mathrm{H}_{2} \mathrm{SO}_{4}$ were added. After heating at $200^{\circ} \mathrm{C}$ till solution was clear, samples were cooled and filtered into standard $50 \mathrm{ml}$. volumetric flask and made to the volumetric mark. The digest were analyzed for $\mathrm{Fe}, \mathrm{Zn}, \mathrm{Cu}, \mathrm{Ni}, \mathrm{Cd}, \mathrm{Pb}, \mathrm{Cr}, \mathrm{Hg}$, As and $\mathrm{Mn}$ by flame atomic absorption spectrometer, Perkin Elmer Model A-analyst 700. Automatic mercury analyzer model HG-500 was used for the determination of Hg. Blanks and standards were also prepared alongside for effective calibrations.

\subsection{Statistical Analysis}

Statistical analysis of data generated was performed by subjecting the data to analysis of variance (ANOVA) to calculate significant difference in treatment means and Duncan was used to separate the means (13).

\section{RESUlts}

The result of some heavy metals present in five different seasoning/spices sold along five major highways in Ogun State, South west, Nigeria are shown in Table 1.

\begin{tabular}{|l|l|l|l|l|l|}
\hline Heavy metal & Onion & Nutmeg & Garlic & Ginger & Pepper \\
\hline $\mathrm{Fe}$ & $0.26 \pm 0.01$ & $1.33 \pm 0.01$ & $1.71 \pm 0.01$ & $0.50 \pm 0.000$ & $0.45 \pm 0.01$ \\
\hline $\mathrm{Zn}$ & $0.17 \pm 0.01$ & $0.86 \pm 0.03$ & $1.18 \pm 0.00$ & $0.34 \pm 0.01$ & $0.21 \pm 0.02$ \\
\hline $\mathrm{Cu}$ & $0.28 \pm 0.01$ & $0.56 \pm 0.01$ & $0.76 \pm 0.02$ & $0.40 \pm 0.01$ & $0.21 \pm 0.02$ \\
\hline $\mathrm{Ni}$ & $\mathrm{ND}$ & $\mathrm{ND}$ & $\mathrm{ND}$ & $\mathrm{ND}$ & $\mathrm{ND}$ \\
\hline $\mathrm{Cd}$ & $0.01 \pm 0.00$ & $0.01 \pm 0.00$ & $0.01 \pm 0.00$ & $0.01 \pm 0.01$ & $0.01 \pm 0.01$ \\
\hline $\mathrm{Pb}$ & $0.001 \pm 0.00$ & $0.001 \pm 0.01$ & $0.001 \pm 0.01$ & $0.001 \pm 0.01$ & $0.001 \pm 0.01$ \\
\hline $\mathrm{Cr}$ & $\mathrm{ND}$ & $\mathrm{ND}$ & $\mathrm{ND}$ & $\mathrm{ND}$ & $\mathrm{ND}$ \\
\hline $\mathrm{Hg}$ & $\mathrm{ND}$ & $\mathrm{ND}$ & $\mathrm{ND}$ & $\mathrm{ND}$ & $\mathrm{ND}$ \\
\hline $\mathrm{Ar}$ & $\mathrm{ND}$ & ND & ND & ND & ND \\
\hline $\mathrm{Mn}$ & $0.21 \pm 0.01$ & $0.46 \pm 0.03$ & $0.56 \pm 0.01$ & $0.32 \pm 0.01$ & $0.36 \pm 0.02$ \\
\hline
\end{tabular}

\section{DISCUSSION}

Some notable heavy metals such as Iron $(\mathrm{Fe})$, Zinc $(\mathrm{Zn})$, Copper $(\mathrm{Cu})$, Nickel $(\mathrm{Ni})$, Cadmium $(\mathrm{Cd})$, lead $(\mathrm{Pb})$, Chromium $(\mathrm{Cr})$, Mercury $(\mathrm{Hg})$, Arsenic (As) and Manganese $(\mathrm{Mn})$ were determined by atomic absorption spectrophotometry method in five seasoning sold along major highways in Ogun State, South West, Nigeria and the results are as presented in Table1. The results are means of three replicates with standard deviation. The iron content ranged from $0.26 \mathrm{mg} / \mathrm{kg}$ in onion to $1.71 \mathrm{mg} / \mathrm{kg}$ in garlic. Iron is most needed micronutrients in plants $(4,14)$. The levels of iron in ginger and garlic are lower than those reported in a previous work. $(15,16,17)$. Iron is an essential element and it is a constituent of active site of various reproductive hydrogenase, most frequently associated with sulphur containing glands. Iron together with hemoglobin and pyridoxine plays a central role of metabolism. Iron facilitates the oxidation of carbohydrate, protein and fat to control the body weight which is an important factor is some diseases such as diabetes (18). As reported in a previous work (4), iron is an essential element needed by the body and consumption of an excessive amount can lead to health effects such as enlarged liver and joint diseases. The Recommended Daily Allowance (RDA) of $14.8 \mathrm{mg} / \mathrm{day}$ of iron for a $60 \mathrm{~kg}$ body weight has not been met (3) as reported in the literature (4), therefore other source of this important micro nutrient must be introduced into food. The level of Zinc are $0.17 \mathrm{mg} / \mathrm{kg}$ (onion), $0.86 \mathrm{mg} / \mathrm{kg}$ (Nutmeg), $1.18 \mathrm{mg} / \mathrm{kg}$ (garlic), $0.34 \mathrm{mg} / \mathrm{kg}$ (ginger) and $0.12 \mathrm{mg} / \mathrm{kg}$ (pepper) for all the five seasonings been investigated. Zinc plays important roles in growth and development in humans $(4,19)$. The level of Zinc, which ranged from $0.12 \mathrm{mg} / \mathrm{kg}$ [pepper] to $1.18 \mathrm{mg} / \mathrm{kg}$ [garlic] are extremely low when compared with a previous work $[4,14,17]$ and are also lower than the standard level $[100 \mathrm{mg} / \mathrm{kg}]$ set by $\mathrm{FAO} / \mathrm{WHO}(20)$. A similar work (21) reported that the 
estimated $20 \%$ of the world population was at risk of inadequate zinc intake. The lowest and highest levels of copper were found to be $0.12 \mathrm{mg} / \mathrm{kg}$ in pepper to $0.76 \mathrm{mg} / \mathrm{kg}$ in garlic. Copper is essential enzymatic element and are necessary for normal biological activities of amino oxide and tyrosinase enzyme. Tyrosinase is the enzyme that is required for catalytic conversion of tyrosinase to melanin which is a vital pigment located beneath the skin and thus protect the skin from dangerous radiations $(16,22)$. Copper also helps in iron metabolism by helping in oxygen transport as well as utilization and absorption of iron in humans (4,23). However, WHO limit in seasoning is $50 \mathrm{mg} / \mathrm{kg}$.

Cadmium level for all the five seasonings ranged from $0.001 \mathrm{mg} / \mathrm{kg}$ in onion and pepper to $0.01 \mathrm{ml} / \mathrm{kg}$ in nutmeg, garlic and ginger respectively, suggesting a little variation in the concentration of the metal. For example, the permissible limit for cadmium is $6 \mathrm{mg} / \mathrm{kg}$ for all foods in Pakistan $(24,25)$. Cadmium has been reported that it presence in food is mostly derived from various source of environmental contamination, has no biological importance in higher organism such as humans and plants (26). All the seasonings are found to contain low level of cadmium and in contrast to $3.1 \mathrm{mg} / \mathrm{kg}$ reported earlier in a previous work (17).

A similar trend was revealed on the concentration of lead in all samples, ranging from $0.001 \mathrm{mg} / \mathrm{kg}$ in onion and pepper to $0.01 \mathrm{mg} / \mathrm{kg}$ in other seasonings, i.e nutmeg, garlic and ginger. Lead $(\mathrm{Pb})$ is a heavy metal poison which form complexes with oxo-group in enzymes to affect virtually all step in the process of hemoglobin synthesis and porphyrin metabolism $(25,27)$. The level of lead in all the samples pose no threat to consumers of these seasoning around the area understudy since the level are below $0.3 \mathrm{mg} / \mathrm{kg}$ stipulated by FAO/WHO (20). Manganese level in all the samples varied from $0.21 \mathrm{mg} / \mathrm{kg}$ in onion to $0.56 \mathrm{mg} / \mathrm{kg}$ in garlic. Manganese is one of the major minerals, which is related to the carbohydrate and fat metabolism (22). The major source of manganese in soil are fertilizer, sewage sludge and ferrous smelters. Daily dietary intake of $2.5 \mathrm{mg} / \mathrm{kg}$ manganese is considered to be suitable for human adults. (22).

Nickel, Chromium, Mercury and Arsenic were not detected in all the sample under consideration. Nickel regulates the mineral metabolism, enzyme activity and several other metabolic processes in plants. It can also be used as fungicide and well toxic to the germination of some seed (22). Chromium is one of the known pollutant in the world. At an elevated concentration, it is toxic for both plant and animals. The problems that are associated with chromium involve skin rashes, stomach ulcer, kidney, liver damages, lungs cancer and ultimate death. (22). Nickel and mercury also met WHO (20) Limits of $50 \mathrm{mg} / \mathrm{kg}$ and $10 \mathrm{mg} / \mathrm{kg}$ respectively since non were detected in all the samples (28).

\section{Conclusion}

It is evident from this work that heavy trace metal contents of some seasonings sold along major highways in Ogun State, South West, Nigeria are within safe limits stipulated by relevant standard bodies and therefore would not pose any serious health challenges to the consumers, though, most of these seasonings are always covered with protective materials such as tarpaulin and primary washing prior to analyses would have greatly reduce their concentrations.

\section{REFERENCES}

[1] Imtiazm, T and Sievers, H (2010): Contaminants of medicinal and Food herb with a view to EU regulations. In: Food Technology: 25-27

[2] Ward, E.O (1995): The case for indigenous West African Food Culture. UNESCO Dakar Regional Office (Breda) Dakar. Breada series, NO9:1-19

[3] FAO (2009): Corporate Document Repository Plants as Storage Pesticides. (http://www.fao.org/ docrep/×2230e/2230e05.htm).

[4] Darko, B, Ayim, I and Voegborlo, R.B (2014): Detection of Heavy metal content of pepper and seasoning on the Ghanaian market. African Journal of Food Science. 8(1): 14-19.

[5] Ansari, T.M, Ikram, N, Najam-ul-Hag, M, Fayyaz, O, Ghafoor I and Khalid, N (2004): Essential trace metal ( $\mathrm{Zn}, \mathrm{Mn}, \mathrm{Cu}$ and $\mathrm{Fe}$ ) Level in plants of medical importance. J. Biol. Sci. 4: 95-99

[6] Duruibe, J.O, Ogwuegbu, M. O.C, and Egwurugbu, J.N (2007): Heavy metal pollution and human biotoxic effect. Int. J. Phys. Sci. 2(5): 112-118 
[7] Opuene, K and Agbozu, I.E, (2008): Relationships between Heavy metals in Shrimp (Macro brachium felicinum) and metal level in the Water Column and Sediments of Taylor Creek. Int. J. Environ. Reps. 2(4): 343-348

[8] Scuily. T. (1995): Lead intoxication epidemic caused by ingestion of contaminated ground paprika. J. Toxicol. Clin. Toxicol. 34:507-511.

[9] Bailey, M.A, Polansky, M.M and Anderson, R.A (1992): Trace element Biol. Res. 32: 117-121.

[10] Luke, J.A (1997): Effect of Fluoride on the physiology of the pineal gland. A dissertation submitted to the school of Biological Sciences, University of Survey: 1-9; 51-53

[11] Lanntech (2008): Water Treatment and Air Purification. Water Treatment. Published by lenntech, Rotter Dansewage. Netherlands. www.excalwater.com/http/filter/water.purification htm. Lopez FF, Cabrera C.

[12] Akagi, H and Nishimura, H (1991): Speciation of mercury in the environment. In:T.Suzuki NI, Clarkson (Eds). Adrances in mercury toxicology. New York, USA: Plenum Press: 53-76

[13] Duncan, D.B (1955): Multiple range and Multiple F. Test, Biometric, 1-42

[14] Divrikli, U, Horzum, N, Soylak, M and Elci, L (2006): Trace heavy metal content of some spies and herbal plants from Western Anatolia, Turkey. Int. J. Food Sci. Technol. 41: 712-716

[15] Ozkutlu, F, Metin Kara, S and Sekeroglu, N (2006): Monitoring of cadmium and Micro nutrients in spices commonly consumed in Turkey. J. Agric. Biol. 2(5): 223-266

[16] Hashmi, D.R, Shahnaz, I and Shaikh, G.H (2007). Assessment of the level of trace metals in commonly edible vegetable locally available in the market of Karachi city. Pak. J. Bot. 39(3): 747-751.

[17] Koc, H and Sari, H (2009): Trace Metal. Contents of some medicinal Aromatic Plant and soil Sample in the Mediterranean Region. Turkey. J. Appl. Chem. Res. 8: 2-57

[18] Rajukar, N.S and Perdeshi, B (1997): Applied Radiat. Isot, 48: 1059

[19] Colak, H, Soylak, M and Turkuglu, O. (2005): Determination of trace metals content of various herbal and fruit teas produced and marketed from Turkey. Trace Elem. Electrolytes, 22: 192-195

[20] FAO/WHO (2003): Sixty first report of the joint FAO/WHO Expert Committee on Food Additives and Evaluation of certain Food Additives and Contaminants. Codex stand. 230-2001, Rome.

[21] Hotz, C and Brown, K.H (2004): International Zinc Nutrition Consultative Group (IZINCG) Technical NO1. Assessment of the Risk of Zinc deficiency in populations and options of its control. Food Nutri. Bull .25:5130-5162

[22] Kimani, M.Z, Mohiuddin, S, Na2, F, Naqvi, I.T and Zahir, E (2011): Detection of heavy metals in pepper. J. Basic Applied Science. 7(2) 89-95

[23] Ozpelik, D, Toplan, S, Ozdemir, S and Akyoku, M.C (2002): Effects of excessive copper intake on hematological and hemorheological parameters. Biomed. Life Sci. 88 (1) 35-42

[24] Walker, J.M (1981): Proceedings $\mathrm{NO}_{2}$ "Cadmium Accumulations in Australtin Agriculture: National Symposium, Canberra, 1-2 March 1988", Australian Government Publishing Services Canberra, 176-185.

[25] Mubeen, H, Naeem, I, Taskeen, A and Saddiqe, Z(2009): Investigation of Heavy Metals in Commercial Spices Brand, New York Science Journal, 2 (5): 20-26.

[26] Adriano, D (1984): Trace metals in the terrestrial environment. New York: Verlag Spiegler.

[27] Ademorati, C.M.A (1996): Environmental Chemistry and Toxicology Pollution by Heavy metals. Foludex press, Ibadan: 171-172.

[28] Nkansah, M.A and Opoku Amoako, C (2010): Detection of Heavy metal content in pepper and some common spices available in markets in the Kumasi metropolis of Ghana. American Journal of Scientific and Industrial Research. 1 (2): 158-163. 